\title{
The effect of methylxanthines on milk volume and composition, and growth of rat pups
}

\author{
BY ALEXANDRA D. HART* AND R. F. GRIMBLE $\dagger$ \\ Nutrition Department, School of Biochemical and Physiological Sciences, Medical and Biological \\ Sciences Building, Southampton University, Bassett Crescent East, Southampton SO9 $3 T U$
}

(Received 5 February 1990 - Accepted 30 March 1990)

\begin{abstract}
A study was conducted to investigate the effect of differential dose levels of methylxanthines on lactational performance, with respect to milk volume and composition and pup growth. The methylxanthines; caffeine, theophylline and theobromine, were administered via drinking water in the proportions occurring in tea, at a dose of 50,1 and $2 \mathrm{mg} / \mathrm{kg}$ body-weight respectively to Wistar albino rats throughout pregnancy and for up to the 14th day of lactation. A fourth group received a mixture of all three methylxanthines. Maternal food and fluid intake and weight changes, as well as weight gain in the litter were monitored thrice weekly. Milk samples were collected from the dams on days 7 and 14 of lactation, while milk volume was measured on days 12-13 by a method using tritiated water. Results showed that caffeine and theobromine significantly enhanced litter weight $(P<0.01$ and 0.05 respectively). In the caffeine group, enhanced litter growth was due to a significant increase $(P<0.05)$ in milk volume, consequent to increased maternal food intake $(P<0.05)$. In the theobromine group there was only a weak association between increased litter weight and milk volume. Theophylline had no effeet on the volume or composition of milk, or litter weight. The combination of all three methylxanthines also failed to produce any of the positive effects observed with separate drug treatments.
\end{abstract}

Methylxanthines: Lactational performance: Growth: Rat

Caffeine, theophylline and theobromine are related purine compounds referred to as methylxanthines. Methylxanthines are commonly consumed dietary components and occur in coffee, tea, cocoa and cocoa products. Other sources are caffeinated soft drinks, kolanut and some patent medicines such as Beechams powder. Coffee contains mainly caffeine, while tea contains caffeine, theobromine and theophylline. Cocoa products contain primarily theobromine.

Methylxanthines are rapidly and completely absorbed when ingested, and have a wide spectrum of effects such as an increase in the metabolic rate, diuresis, stimulation of the central nervous system and relaxation of smooth muscle (Ritchie, 1975; Acheson et al. 1980). Studies by other investigators also show that methylxanthines induce lipolysis in adipose tissue through the elevation of catecholamines, resulting in the elevation of plasma free fatty acids (Bellet et al. 1968, 1969; Acheson et al. 1980; Patwardhan et al. 1980).

For many years it was reported (Bellet et al. 1969, Daubresse et al. 1973, Ritchie, 1975; Patwardhan et al. 1980) that methylxanthines exerted their broad spectrum of effects through inhibition of phosphodiesterases, the enzymes involved in the degradation of cyclic AMP. In this way, they would elevate the concentration of cyclic AMP which then mediated the various effects seen. This concept, however, does not seem to explain certain physiological events such as decreased, rather than increased, levels of cyclic AMP in the central nervous system (CNS) produced by theophylline as reported by Daly (1977). Second, Kakiuchi et al. (1975) and Smellie et al. (1979) have indicated that caffeine and

* Present address: Department of Food Science \& Technology, University of Science \& Technology, PMB 5080, Nkpolu, Port Harcourt, Nigeria.

$\dagger$ For reprints. 
theophylline are relatively weak inhibitors of most phosphodiesterase isoenzymes, and never attain brain concentrations $(500-1000 \mu \mathrm{M})$ sufficient to cause a marked inhibition of such enzymes. Daly et al. (1981) have also indicated that caffeine inhibits phosphodiesterase at the high concentration of $0.5-1 \mathrm{~mm}$ normally not found in human tissues. Furthermore, analogous inhibitors of phosphodiesterase which cause far more potent inhibition of phosphodiesterase than caffeine or theophylline, have failed to produce more potent stimulation. It has similarly proved difficult to demonstrate any change in tissue or body fluid levels of cyclic AMP following administration of theophylline (Daly, 1977).

The pharmacological effects of methylxanthines are seen at micromolar concentrations; brain and blood levels after coffee consumption are 10-15 $\mu \mathrm{M}$. In asthma where theophylline is used therapeutically, plasma levels of $40 \mu \mathrm{M}$ have been observed; however, convulsions occur at concentrations of $200 \mu \mathrm{M}$ (Gould et al. 1984). The Special Report on the Third International Caffeine Workshop (Anon, 1981) indicated measurable levels of $10-280 \mu \mathrm{M}$ at which various pharmacological effects can be produced. At levels in excess of $400 \mu \mathrm{M}$ they reported that lethality in humans can be expected.

In view of such evidence, it is questionable whether methylxanthines might be mediating their effects through inhibition of phosphodiesterase. There is now strong evidence that another mechanism, namely antagonism to endogenous adenosine, could be responsible for certain effects of methylxanthines since adenosine is structurally analogous to methylxanthines and has opposite effects (Daly, 1977; Fredholm, 1978, 1980; Daly, 1981; Fredholm \& Persson, 1982; Gould et al. 1984).

Caffeine and theophylline at micromolar concentrations have now been found to block the interaction of adenosine with its extracellular receptors. Such adenosine receptors govern a variety of physiological functions (Daly, 1982; Newby, 1982) and appear to represent likely loci for the expression of pharmacological activity of caffeine and theophylline.

A large body of literature indicates that methylxanthines are easily transferred through the plasma and other tissue fluids, including amniotic fluid and cerebrospinal fluid (Axelrod \& Reichenthal, 1953; Yurchak \& Jusko, 1978; Ogilvie, 1985), through the placenta (Horning et al. 1975; Parsons et al. 1976) and through breast milk (Resman et al. 1977; Tyralla \& Dodson, 1979; Berlin, 1981). In recent years there has been an increase in the consumption of beverages containing methylxanthines by all age-groups, including pregnant and lactating women (Graham, 1978). The resurgence of breast feeding (Hartman $\&$ Prosser, 1984) means that an increasing number of infants will be exposed to the presence of methylxanthines. What effect these ubiquitous food components might have on breastfed infants has yet to be established. While studies have indicated possible risk effects of methylxanthines on pregnancy, Hart \& Grimble (1990) demonstrated that caffeine and theobromine have growth-promoting effects on rat pups. Zoumas \& Tarka (1976) also reported a growth-stimulating effect of theobromine on weanling rats. These findings have motivated the present investigation into the effects of methylxanthines on lactational performance with a view to exploring the mechanism by which litter growth is affected. In the present study milk volume and composition were measured. The study also examined whether methylxanthines change the extent of maternal depot fat mobilization by examining the fatty acid contents of milk and maternal depot fat from animals receiving three different methylxanthines or a mixture of all three.

The various doses of methylxanthines used in the study were chosen on an empirical basis, derived from the results of previous investigations in our laboratory, and on the proportions of methylxanthines found in tea. Animals were not, therefore, exposed to equimolar quantities of each methylxanthine but rather to proportions found in a beverage which contains all three. The different dose levels may be justified on the grounds that the 
methylxanthines have varying potencies resulting in differential metabolic effects (Ritchie, 1975). In previous studies the administration of $50 \mathrm{mg}$ caffeine showed positive effects on rats (Hart \& Grimble, 1990). The choice of the theobromine level was reinforced by studies on mice in the same laboratory (A. Bakkum and R. F. Grimble, unpublished results), which demonstrated that administration of 1 and $2 \mathrm{mg}$ theobromine/ $\mathrm{kg}$ body-weight produced significant pup growth, beyond which level $(5 \mathrm{mg} / \mathrm{kg})$ no further increase was achieved.

\section{MATERIALS AND METHODS}

Caffeine (1,3,7-trimethylxanthine) was obtained from BDH Chemicals Ltd, Poole, Dorset, and theophylline (1,3-dimethylxanthine) and theobromine (3,7-dimethylxanthine) from Sigma Chemical Co, Poole, Dorset. Standard laboratory chow (PRD), obtained from Labsure, Manea, Cambridgeshire, contained $198 \mathrm{~g}$ protein $/ \mathrm{kg}$ and $28 \mathrm{~g}$ fat $/ \mathrm{kg}$.

Virgin albino Wistar rats, weighing $200-220 \mathrm{~g}$, were housed individually in wired solidbotlomed cages and fed on a pelleted diet (PRD) throughout the study. The rats were mated separately with age-matched male rats, and the day on which a vaginal plug was found was counted as day 0 of pregnancy. The male rats were separated from the females which were then weighed, and the respective drug treatments initiated.

Caffeine, theophylline and theobromine were administered via drinking water in the proportions occurring in tea (Graham, 1978). Rats received $50 \mathrm{mg}$ caffeine, $1 \mathrm{mg}$ theophylline and $2 \mathrm{mg}$ theobromine $/ \mathrm{kg}$ body-weight per d. To examine the possible effects of tea-drinking on the lactating mother, a further group was included, that received a combination of $50 \mathrm{mg}$ caffeine, $1 \mathrm{mg}$ theophylline and $2 \mathrm{mg}$ theobromine $/ \mathrm{kg}$ body-weight. At least five rats were used in each group, picked at random and assigned to either caffeine, theophylline, theobromine or a mixture of all three drugs. The appropriate amount of each drug was dissolved in distilled water by gentle heating, made up to volume and stored at $0^{\circ}$ in aspirators for no longer than 1 week at a time. A control group received plain drinking water stored under the same conditions as the drug solutions.

All animals had free access to food and fluid, with a lighting schedule of $14 \mathrm{~h} \mathrm{light}$ and $10 \mathrm{~h}$ dark. Room temperature was maintained at $22 \pm 2^{\circ}$. Food and fluid consumption and weight changes in the dams were recorded every $2 \mathrm{~d}$ throughout the gestation and lactation periods. About $3 \mathrm{~d}$ before the expected date of delivery, the dams were transferred to Macrolon boxes with bedding and nesting materials. Litters born before 16.00 hours on any day were designated birthdate 0 .

At $3 \mathrm{~d}$ post partum litter sizes were adjusted to eight pups per dam. This standardization is in accordance with the findings of Wilde \& Kuhn (1979) who demonstrated that litter size affects mammary tissue weight and, thus, milk production which will ultimately influence litter growth.

Weight changes in the dams and litter, and food and fluid consumption of the dams were monitored thrice weekly until $14 \mathrm{~d}$ post partum. The dams were then separated from their litter and decapitated for further studies.

Maternal carcass fat was determined after evisceration of the carcass, and oven-drying at $105^{\circ}$ to obtain a constant weight. The loss of weight gave the water content. The dried carcass was then finely ground with $2-2.5$ times its weight of anhydrous sodium sulphate to obtain a homogeneous mixture. A portion of each sample was transferred to a Soxhlet thimble and further re-dried in the oven to remove any water taken up during grinding. Fat was extracted from the dried carcass samples in duplicate with light petroleum (b.p. $60-80^{\circ}$ ) in a Soxhlet apparatus. The thimble was then drained of all solvent and further dried in an oven. Carcass fat was calculated from the difference in weight of the thimble before and after extraction. 


\section{Milking procedure}

Separate groups of dams were milked on days 7 or 14 of lactation under diethyl ether anaesthesia. Milk $(2 \mathrm{ml})$ was collected by means of manual expression of the ventral thoracic and abdominal teats, and stored at $-20^{\circ}$ until analysed for total protein, fat and lactose.

\section{Milk volume measurement}

Milk volume was measured between 10.00 hours on day 12 and 10.00 hours on day 13 of lactation using a modification of the method of Rath \& Thenen (1979). The method involved the separation of the pups from their mothers, and the intraperitoneal injection of $0.2 \mathrm{ml}(10 \mathrm{mCi} / \mathrm{ml})$ of tritiated water into the dam. After $1 \mathrm{~h}$ the pups were replaced and allowed to suck. The ${ }^{3} \mathrm{H}_{2} \mathrm{O}$ content of the dam's blood was maintained at a plateau over a $24 \mathrm{~h}$ period by replacement of drinking water with $17 \mathrm{mCi}$ tritiated water $/ \mathrm{ml}$ (plus the appropriate dose of methylxanthine). At the end of this period a blood sample was taken from the mother and the pups weighed, killed and homogenized in distilled water.

The ${ }^{3} \mathrm{H}$ content in the dam's plasma and pups' homogenate was calculated to derive the volume of milk produced by the mother and the milk intake of the pups. This measurement is based on the assumption that all radioactivity in the pup comes from the milk obtained from the mother. It also assumes that all or most of the radioactivity stays in the body water. The validity of the latter assumption was tested by estimating the radioactivity that was: (a) lost in the pups' urine, (b) incorporated into the pups' body lipids, and (c) taken up into milk solids. Losses from these routes amounted to less than $8 \%$ of the administered dose.

\section{Determination of radioactivity}

Radioactivity in samples was measured by liquid scintillation counting using Phillips liquid-scintillation analysers, model PW4700. Counting efficiency was $64 \%$ for ${ }^{14} \mathrm{C}$ and $28 \%$ for all ${ }^{3} \mathrm{H}$. Variations in quenching were corrected by external standardization using programme quench curves and the counts expressed as disintegration per minute (dpm). The scintillants used were tritoscint or Beckman Ready-Solve (High Wycombe, UK) as appropriate.

\section{Determination of total protein, lactose and triacylglycerol concentration of milk} A portion $(100 \mu \mathrm{l})$ of rat milk was precipitated with $2.5 \mathrm{ml} 1 \mathrm{M}$-trichloroacetic acid (TCA). The resultant supernatant fraction was reserved for the assay of lactose. The precipitate was washed with $5 \mathrm{ml} \mathrm{TCA}(50 \mathrm{~g} / \mathrm{l})$ dissolved at $37^{\circ}$ in $2 \mathrm{ml} 0 \cdot 3 \mathrm{~m}$-potassium hydroxide, and assayed for total protein by the method of Lowry et al. (1951).

Lactose was measured in the neutralized supernatant fraction by an enzymic method using lactose-galactose kits supplied by Boehringer (Mannheim, West Germany).

Milk triacylglycerol was measured after extraction in propan-2-ol by AutoAnalyzer (Technicon Instruments Co. Ltd, 1971), Triolein was used as the standard.

\section{Determination of the fatty acid composition of milk, maternal uterine fat and stock diet fat}

Fatty acid composition was determined on milk samples taken on days 7 and 14 for comparison with the uterine depot fat and stock-diet fat.

Lipid extraction was carried out using a mixture of chloroform-methanol, $(2: 1, \mathrm{v} / \mathrm{v})$. The fatty acid composition was then estimated by gas-liquid chromatography. The system used (Pye Unicam 305) was equipped with a $50 \mathrm{~m} \times 0.22 \mathrm{~mm}$ internal diameter fused silica capillary column coated with CP sil 88, 0.18 thick (Chrompak) using a hydrogen carrier.

The peak areas were determined by computerized electronic integration using the 
Table 1. Food and fluid intakes and weight changes of dams administered methylxanthines during pregnancy and lactation

(Mean values with their standard errors)

\begin{tabular}{|c|c|c|c|c|c|c|c|c|c|c|c|c|c|}
\hline \multirow{4}{*}{$\begin{array}{l}\text { Treatment } \\
\text { groupt }\end{array}$} & \multirow[b]{4}{*}{$n$} & \multirow{2}{*}{\multicolumn{4}{|c|}{$\begin{array}{l}\text { Food intake } \\
\text { (g/dam per d) }\end{array}$}} & \multirow{2}{*}{\multicolumn{4}{|c|}{$\begin{array}{l}\text { Fluid intake } \\
\text { (ml/dam per d) }\end{array}$}} & \multicolumn{4}{|c|}{ Body-wt changes } \\
\hline & & & & & & & & & & & & Lac & tion \\
\hline & & Pregn & ncy & Lacta & & Pregn & ney & Lacta & & $(\mathrm{g} / \mathrm{d} t$ & $d$ & $\mathrm{~g} / \mathrm{dam}$ & er $10 \mathrm{~d}$ ) \\
\hline & & Mean & $\mathbf{S E}$ & Mean & $\mathbf{S E}$ & Mean & $\mathrm{SE}$ & Mean & $\mathrm{SE}$ & Mean & $\mathrm{SE}$ & Mean & $\mathrm{SE}$ \\
\hline Control & 7 & 24 & 0.9 & 36 & $0 \cdot 6$ & 32 & $1 \cdot 5$ & 49 & 1.5 & 6 & 0.3 & 9 & $4 \cdot 3$ \\
\hline Caffeine & 5 & 26 & 0.9 & $40^{* *}$ & $1 \cdot 0$ & $37^{*}$ & 1.4 & $66^{* *}$ & $3 \cdot 6$ & 5 & $0 \cdot I$ & 10 & $13 \cdot 0$ \\
\hline Theophylline & 5 & 23 & 0.4 & 34 & 0.6 & 29 & $2 \cdot 5$ & 54 & $6 \cdot 1$ & 5 & 0.5 & 9 & $4 \cdot 0$ \\
\hline Theobromine & 5 & 24 & 0.6 & 36 & $1 \cdot 5$ & 27 & 0.8 & 46 & 1.7 & 6 & $0-2$ & 2 & $4 \cdot 8$ \\
\hline Mixture & 5 & 27 & $0 \cdot 9$ & 40 & $2 \cdot 4$ & 32 & 1.9 & 54 & $3 \cdot 8$ & 6 & 0.4 & 11 & $2 \cdot 8$ \\
\hline
\end{tabular}

Mean values were significantly different from those of the control group (Student's $t$ test): ${ }^{*} P<0 \cdot 05$, ** $P<0.01$.

+ For details, see p. 341 .

following fatty acid standards: $C_{10: 0}, C_{12: 0}, C_{14: 0}, C_{14: 1}, C_{16: 0}, C_{18: 0}, C_{18: 1}, C_{18: 2}, C_{18: 3}$, $\mathrm{C}_{20: 4}, \mathrm{C}_{20: 5}, \mathrm{C}_{20: 6}$. Results are expressed as fatty acid percentage composition by weight.

\section{Statistical analysis}

Results are expressed as mean value with their standard errors. Tests of significance between control and individual-methylxanthine groups were carried out using Student's unpaired $t$ test.

\section{RESULTS}

The results of food and fluid intake are presented in Table 1. Food intakes during pregnancy were not significantly different between control and the methylxanthine-treated groups. During lactation the caffeine group consumed significantly more food than the controls $(P<0.01)$. The group receiving the mixture of methylxanthines had a larger mean food intake than the control group, although the difference did not reach statistical significance.

Fluid intake was significantly greater in the caffeine group during pregnancy and lactation, compared with the control group ( $P<0.05$ and $P<0.002$ respectively).

Body-weight changes of the dams (Table 1) showed no significant differences between groups during pregnancy or lactation. Litter weights (Table 2) were similar at day 3 of lactation; however, they were significantly greater in the caffeine and theobromine groups $(P<0.01$ and $P<0.05$ respectively) at $13 \mathrm{~d}$ post partum. Litter growth showed a significant increase in the caffeine group $(P<0.005)$. The theobromine group, however, showed no significant change.

Caffeine treatment significantly enhanced milk volume $(P<0.05$; Table 3$)$, but the total daily production of protein, lactose and triacyglycerols in milk were not significantly altered in any of the groups.

Values for the fatty acid composition of milk fat sampled on days 7 and 14 are presented in Table 4. Methylxanthine treatment produced no significant differences in the milk fatty acid profile.

The major fatty acids in all groups were: palmitate $\left(\mathrm{C}_{16: 0}\right)$, oleate $\left(\mathrm{C}_{18: 1}\right)$, linoleate $\left(\mathrm{C}_{18: 2}\right)$ and the medium-chain fatty acids $\left(\mathrm{C}_{10: 0}-\mathrm{C}_{14: 0}\right)$. With the progression of lactation from day 7 to 14 , there was an increase in the proportion of the medium-chain fatty acids and a 
Table 2. Effect of methylxanthines on litter weight in rats

(Mean values with their standard errors)

\begin{tabular}{|c|c|c|c|c|c|c|c|}
\hline \multirow{3}{*}{$\begin{array}{l}\text { Treatment } \\
\text { group } \dagger\end{array}$} & \multirow[b]{3}{*}{$n$} & \multicolumn{4}{|c|}{ Litter wt (g) } & \multirow{2}{*}{\multicolumn{2}{|c|}{$\begin{array}{l}\text { Litter growth rate } \\
\qquad(\mathrm{g} / \mathrm{d})\end{array}$}} \\
\hline & & \multicolumn{2}{|c|}{ Day 3} & \multicolumn{2}{|c|}{ Day 13} & & \\
\hline & & Mean & SE & Mean & $\mathrm{SE}$ & Mean & $\mathrm{SE}$ \\
\hline Control & 7 & 66 & 1 & 183 & 5 & $11 \cdot 7$ & 0.6 \\
\hline Caffeine & 5 & 69 & 3 & $213^{* *}$ & 7 & $14 \cdot 4 * * *$ & 0.5 \\
\hline Theophylline & 5 & 63 & 1 & 189 & 2 & $12 \cdot 6$ & $0 \cdot 3$ \\
\hline Theobromine & 5 & 66 & 2 & $199 *$ & 2 & $13 \cdot 3$ & 0.5 \\
\hline Mixture & 5 & 60 & 2 & 192 & 16 & $13 \cdot 3$ & 0.3 \\
\hline
\end{tabular}

Mean values were significantly different from those of the control group (Student's $t$ test): $* P<0 \cdot 05$, ** $P<0.01, * * * P<0.005$.

$\dagger$ For details, see p. 341 .

Table 3. Effect of methylxanthines on the volume and total $24 \mathrm{~h}$ production of protein, lactose and triacylglycerols in milk of rats at day 13 of lactation

(Mean values with their standard errors)

\begin{tabular}{|c|c|c|c|c|c|c|c|c|c|c|}
\hline \multirow[t]{2}{*}{$\begin{array}{l}\text { Treatment group }{ }^{\dagger} . . \\
n \ldots\end{array}$} & \multicolumn{2}{|c|}{$\begin{array}{c}\text { Control } \\
6\end{array}$} & \multicolumn{2}{|c|}{$\begin{array}{c}\text { Caffeine } \\
6\end{array}$} & \multicolumn{2}{|c|}{$\begin{array}{c}\text { Theophylline } \\
5\end{array}$} & \multicolumn{2}{|c|}{$\begin{array}{c}\text { Theobromine } \\
5\end{array}$} & \multicolumn{2}{|c|}{$\underset{5}{\text { Mixture }}$} \\
\hline & Mean & SE & Mean & $\mathrm{SE}$ & Mean & SE & Mean & $\mathrm{SE}$ & Mean & SE \\
\hline $\begin{array}{l}\text { Milk volume } \\
\text { (ml/dam per d) }\end{array}$ & $45 \cdot 3$ & $2 \cdot 7$ & $53.9 *$ & $3 \cdot 7$ & $45 \cdot 0$ & $2 \cdot 4$ & $51 \cdot 7$ & $2 \cdot 6$ & $47 \cdot 7$ & $3 \cdot 8$ \\
\hline Water $(\mathrm{ml} / \mathrm{l})$ & 755 & 12 & 733 & 9 & 774 & 14 & 733 & 12 & 723 & 12 \\
\hline $\begin{array}{l}\text { Protein } \\
\text { (g/dam per } d)\end{array}$ & $3 \cdot 4$ & $0 \cdot 3$ & $4 \cdot 3$ & $0 \cdot 3$ & $3 \cdot 1$ & $0 \cdot 3$ & $3 \cdot 5$ & $0 \cdot 1$ & $3 \cdot 5$ & $0 \cdot 4$ \\
\hline $\begin{array}{l}\text { Lactose } \\
\text { (g/dam per d) }\end{array}$ & 0.67 & $0 \cdot 1$ & 0.91 & 0.1 & 0.68 & 0.08 & 0.89 & $0 \cdot 10$ & 0.71 & $0 \cdot 1$ \\
\hline $\begin{array}{l}\text { Triacylglycerols } \\
\text { (g/dam per d) }\end{array}$ & $9 \cdot 8$ & $0 \cdot 7$ & $10 \cdot 8$ & $1 \cdot 1$ & $9 \cdot 0$ & $0 \cdot 6$ & $10 \cdot 9$ & 0.8 & $11 \cdot 5$ & $1 \cdot 2$ \\
\hline
\end{tabular}

Mean value was significantly different from control group (Student's t test): ${ }^{*} p<0.05$.

$\uparrow$ For details, see p. 341 .

decrease in the long-chain unsaturated fatty acids $\left(\mathrm{C}_{18: 1}-\mathrm{C}_{18: 3}\right)$. These results are in agreement with the findings of Chalk \& Bailey (1979).

Comparison of the fatty acid composition of milk fat with those of the uterine fat and the stock-diet fat (Table 5) may indicate its source. The palmitate content of milk fat on days 7 and 14 resembled that of uterine fat (between 25 and $27 \%$ in milk fat compared with $27 \%$ in the uterine fat). The linoleate $\left(\mathrm{C}_{18: 2}\right)$ content of milk fat on days 7 and 14 in all groups was also similar to that of the uterine depot fat. Milk linoleate was also likely to have come from the maternal depot fat, since the proportion of this fatty acid was lower in the former than in the latter. If the diet was a significant source, then a higher proportion would be expected in the milk fat. The source of the depot fat linoleate is dietary, since no known mammal synthesizes this fatty acid (Jenness, 1974).

\section{DISCUSSION}

The results presented in the present study showed that caffeine produced a significant increase in food intake during lactation $(P<0.05)$. Similarly, fluid intake was significantly 


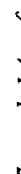

$$
\text { TIN AND LACTATIONAL PERTORMANCE }
$$

Nㅇㅇㅎㅇ $\vec{O} \hat{O} \vec{O} \dot{O}$

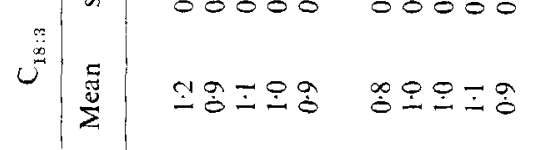

a

$\stackrel{8}{5}$

$\frac{5}{2}$

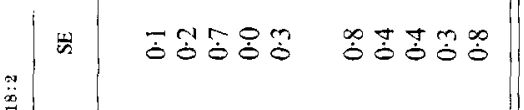

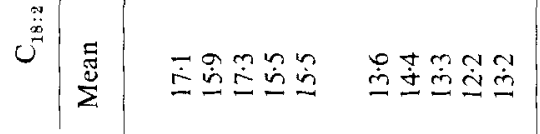

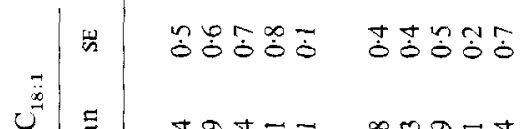

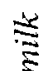

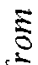

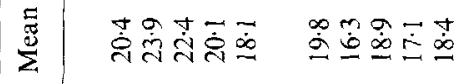

Б어유

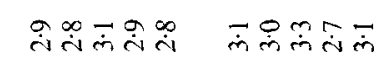

is

5

2

पृींखण

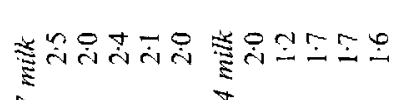

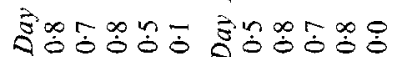
$\pm$

चompa meatan

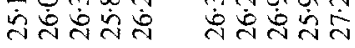

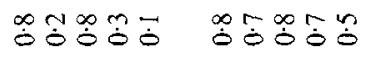

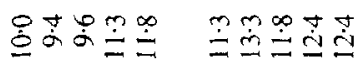

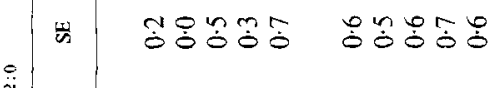

$u^{i}$

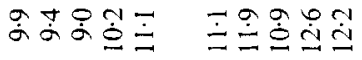

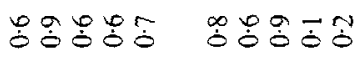

4

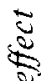

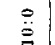

苟

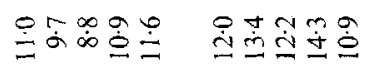

F

音

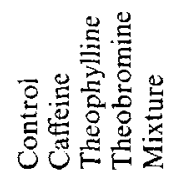


A. D. HART AND R. F. GRIMBLE

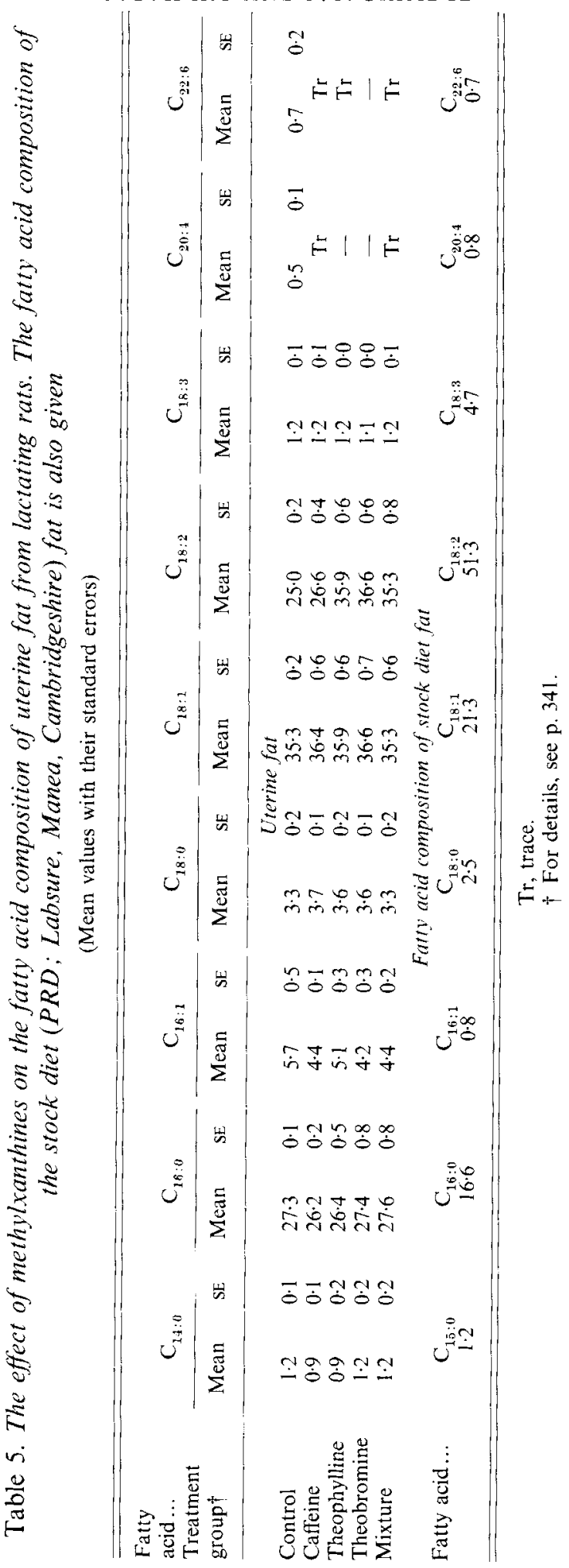


greater in the caffeine group during pregnancy and lactation $(P<0.05$ and $P<0.01)$. Although the group receiving the mixture of methylxanthines showed an elevated mean food intake, the value did not achieve statistical significance.

Milk volume was augmented by caffeine. This phenomenon suggests a relationship between enhanced litter growth and increased milk production, consequent to increased food consumption. In the theobromine group, there was only a weak association between increased litter weight at day 13 and milk volume. The total production of protein, lactose and fat showed an upward trend which did not attain statistical significance.

This is not surprising in spite of the increased maternal food intake, as milk composition is seldom affected except under extreme maternal dietary restrictions: however, milk volume may be affected (Mansaray, 1985).

While caffeine and theobromine had positive effects on litter growth, food and fluid intake and milk production, theophylline provoked no effect on any of these variables. This could be as a result of the low dosage administered to the dams. The mixture of methylxanthines similarly failed to produce any of the stimulatory effects observed with caffeine or theobromine. What is the explanation for this paradoxical effect?

It may be speculated that since theophylline is the most potent antagonist of adenosine, it could result, in the present study, in a lowering of the effects seen in the mixed methylxanthine group. For example, if theophylline bound to a mammary cell receptor and produced little or no effect, it may exclude that receptor from binding to caffeine or theobromine which proved to be more potent drugs as regards stimulation of lactational performance. This proposition is supported by the work of McDaniel et al. (1977) who reported an inhibition of caffeine uptake as well as caffeine displacement by theophylline in isolated pancreatic islet cells, indicative of competition for a common binding site or transport carrier, or both. Although the present study used different dose levels of methylxanthines, using equal doses of the drugs, Aeschbacher \& Wurzner (1975) reported significant stimulation of hepatic microsomal enzyme activity when rats were pre-treated orally with higher doses $(150 \mathrm{mg} / \mathrm{kg})$ of either caffeine, theophylline or theobromine. They observed that stimulation was dose-dependent; thus, while $75 \mathrm{mg} / \mathrm{kg}$ of each drug produced some enzyme induction, a lower dose of $37.5 \mathrm{mg} / \mathrm{kg}$ produced no changes, even with a combination of all three drugs amounting to $112.5 \mathrm{mg}$ methylxanthines $/ \mathrm{kg}$. Although the design of these workers' experiment does not tally with the study being reported, the phenomenon observed in the present study is indicative of possible competition at the receptor site to reduce the positive effect seen with individual methylxanthine treatment.

Methylxanthines exerted no influence on milk fatty acid composition. Fatty acid profiles of milk on days 7 and 14 were not significantly different between control and the drugtreated groups. Comparison between milk fatty acids and the uterine fatty acids showed the former to have a profile typical of rat milk fat. If methylxanthines had increased mobilization of maternal body lipids to augment milk production, milk fatty acid composition would have reflected that of the uterine depot fat and showed an enhanced content of palmitate and oleate, with diminished medium-chain fatty acid content. However, it did not.

On a normal laboratory chow, Williamson (1980) indicated that $50 \%$ of the lipids are synthesized within the mammary gland (de novo synthesis). Among the rodents, rats produce considerable short-chain acids due to the ability to synthesize fat from carbohydrates by conversion of citrate to acetyl $\mathrm{CoA}$ by means of ATP-citrate lyase (EC 4.1.3.8) (Jenness, 1974). The remainder of the milk lipids is derived from triacylglycerols and non-esterified fatty acids taken up from the blood through the diet and from endogenous sources (liver and adipose tissue). Physiological adaptations within the 
maternal tissue involve increased cardiac output, with greatly enlarged mammary glands, as well as organs that supply substrates to the latter organ such as the liver and gastrointestinal tract. These changes result in diversion of a high proportion of the substrates available in circulation. Glucose, triacylglycerols, free fatty acids and ketone bodies are all directed to the mammary gland for the production of milk (Chatwin et al. 1968; Widdowson, 1976; Williamson, 1980). Thus, during lactation some of the components for milk synthesis are supplied directly by the diet, and some from the mother's reserve which ultimately must have come from the diet. In addition to these adaptations in the rat, Naismith et al. (1982) demonstrated a cycle of fat retention during gestation, followed by up to a $60 \%$ mobilization of the dam's body fat during lactation to augment milk production. If methylxanthines were effecting lipolysis as reported by Bellet et al. (1969) and Patwardhan et al. (1980), the released fatty acids would have been directed towards the mammary glands, resulting in a preponderance of milk fatty acids reflecting those of the uterine depot fat. This would have subsequently decreased the need for de novo synthesis. A previous study by Hart \& Grimble (1990) had shown no significant decrease in the carcass fat content of the drug-treated animals, reinforcing the conclusion of a lack of effect of methylxanthines on lipid mobilization and implying that no contribution from adipose tissue that deviated from normal occurred. In summary then, these findings have clearly demonstrated that the fatty acid composition of milk from all groups was a typical profile of rat's milk, derived partly from de novo synthesis (medium-chain fatty acids). The rest of the fatty acids, particularly palmitate and oleate were derived from maternal lipids as a normal physiological process, while others such as linoleate originated from dietary sources, as no known species synthesize this fatty acid.

The deductions from the present study suggest a stimulatory influence of theobromine and caffeine on pup weight. These effects may be due to a combination of factors. In the case of theobromine, there was only a weak association between milk production and enhanced litter weight. The factor responsible for the growth stimulation remains obscure. In the case of caffeine, however, the evidence given in the present study links elevated litter growth with increased maternal milk volume, which in turn may result from increased maternal food intake. Factors responsible for the increased food consumption in the caffeine group, and the mechanism effecting growth stimulation will need to be investigated further.

The authors wish to thank Nestlé Nutrition for providing financial support to carry out the study reported.

\section{REFERENCES}

Acheson, K. J., Zahorska-Markiewicz, B., Petiet, P. H., Anantharam, K. \& Jequier, E. (1980). Caffeine and coffe: their influence on metabolic rate and substrate utilisation in normal weight and obese individuais. American Journat of Clinical Nutrition 33,989-997.

Aeschbacher, H. \& Wurzner, H. (1975). Effect of methylxanthines on hepatic microsomal enzymes in the rat. Toxicology and Applied Phamacology 33, 575-581.

Anon. (1981). Third International Caffeine Workshop. Special Report. Nutrition Reviews 39, $183-191$.

Axelrod, J. \& Reichentha1, J. (1953). The fate of caffeine in man and a method for its estimation in biological materials. Journal of Pharmacology and Experimental Therapeutics 107, 519-523.

Bellet. S., Kershbaum, A. \& Finck, E. M. (1968). Response of free fatty acids to coffee and caffeine. Metabolism 17, $702-707$.

Bellet, S., Roman, L., DeCastro, O., Kim, K. E. \& Kershbaum, A. (1969). Effect of coffee ingestion on catecholamine release. Metabolism 18, $288-291$.

Berlin, C. M. Jr (1981). Excretion of methylxanthines in human milk. Seminars in Perinatology $5,389394$.

Chalk, P. A. \& Bailey, E. (1979). Changes in the yicld and carbohydrate, lipid and protein content of milk during lactation in the rat. Journal of Developmental Physiology 1, 61-79.

Chatwin, A. L., Linzell, J. L. \& Sctchell, B. P. (1969). Cardiovascular changes during lactation in the rat. Journal of Endocrinology 44, $247,254$. 
Daly, J. (1977). Cyclic Nucleotides in the Central Nervous System. New York: Plenum Press.

Daly, J. W. (1982). Adenosine receptors: target for future drugs. Journal of Medical Chemistry 25, $197-207$.

Daly, J. W., Bruns, R. F. \& Snyder, S. H. (I981). Adenosine receptors in the central nervous system: Relationship to the central actions of methylxanthines. Life Sciences 28, 2083-2097.

Daly, J. W., Butts-Lamb, P. \& Padgett, W. (1983). Subclasses of adenosine receptors in the central nervous system: interaction of caffeine and related methylxanthines. Cellular and Molecular Neurobiology 3, 69-80.

Daubresse, J.-C., Luyckx, A., Demey-Ponsart, E., Franchimont, P. \& Lefebvre, P. (1973). The effects of coffee and caffeine on carbohydrate metabolism, free fatty acid, insulin, growth hormone and cortisol plasma levels in man. Acta Diabetologia Latin Americana 10, 1069-1084.

Fredholm, B. B. (1978). Local regulation of lipolysis in adipose tissue by fatty acids, prostaglandins and adenosinc. Review article. Medican Biology 56, 249-286.

Fredholm, B. B. (1980). Are methylxanthine effects due to antagonism of endogenous adenosine? Trends in Phamacological Sciences 1, 129-132.

Fredholm, B. B. \& Persson, C. G. A. (1982). Xanthine derivatives as adenosine receptor antagonists. European Journal of Pharmacology 81, 673-676.

Gould, R. J., Murphy, K. M. M., Katims, J. J. \& Snyder, S. H. (1984). Caffeine actions and adenosine. Psychopharmacology Bulletin 20, 436-440.

Graham, D. M. K. (1978). Caffeine .. its identity, dietary sources, intake and biological effects. Nutrition Review' 36, 97102 .

Hart, A. \& Grimble, R. F. (1990). The effects of methylxanthines on lactational performance. Annals of Nutrition and Melabolism 115 (In the Press)

Hartman, P. E. \& Prosser, C. G. (1984). Physiological basis of longitudinal changes in human milk yield and composition. Federation Proceedings 43, 2448-2453.

Horning, M. G., Butler, C. M., Nowlin, J. \& Hill, R. M. (1975). Mini review: drug metabolism in the human neonate. Life Sciences 16, 65l-671.

Jenness, R. (1974). The composition of milk. In Lactation: A Comprehensive Treatise, vol. 3, pp. 8-12 [B. Larson and V. R. Smith, editors]. New York: Academic Press.

Kakiuchi, S., Yamazaki, R., Teshima, Y., Uenishi, K. \& Miyamoto, E. (1975). Multiple cyclic nucleotide phosphodiesterase activities from rat tissues and occurrence of calcium plus magnesium ion dependent phosphodiesterase and its protein activator. Biochemical Journal 146, 108-120.

Lowry, O. II., Rosenbrough, N. J., Farr, A. L. \& Randall, R. J. (1951). Protein measurement with the Folin phenol reagent. Journal of Biological Chemistry 193, 265-275.

McDanicl, M. L., Weaver, D. C., Roth, C. E., Fink, C. J, Swanson, J. A. \& Lacy, P. E. (1977). Characterisation of the uptake of the methylxanthines thcophylline and caffeine in isolated pancreatic islets and their effect on D-glucose transport. Endocrinology 101, 1701-1708.

Mansaray, Y. K. C. (1985). The effects of protein nutrition on lactational performance. PhD Thesis, University of Southampton.

Naismith, D. J., Richardson, D. P. \& Pritchard, A. E. (1982). The utilisation of protein and energy during lactation in the rat, with particular regard to the use of fat accumulated during pregnancy. British. Journal of Nutrition 48, 433-441.

Newby, A. C. (1984). Adenosine and the concept of retaliatory metabolites. Trends in Biochemical Sciences 9 , $42-44$

Ogilvie, R. I. (1978). Clinical pharmacokinetics of theophylline. Clinical Pharmacokinetics 3, 267 Abstr.

Parsons, W. D., Aranda, J. V. \& Neims, A. (1976). Elimination of transplacentally acquired caffeine in full-term. Pediatric Research 10, 333 Abstr.

Patwardhan, R. V., Desmond, P. V., Johnson, R. F., Dunn, D., Robertson, E., Hoyumpa, A. M. \& Schenker, S. (1980). Effects of caffeine on plasma free fatty acids, urinary catecholamines and drug binding. Clinical Pharmacology and Therapeutics 28, 398-403.

Rath, E. A. \& Thenen, S. N. (1979). Use of tritiated water for measurement of 24 hour milk intake by suckling lean and genetically obese $(o b / o b)$ mice. Journal of Nutrition 109, 840 847.

Resman, B. H., Blumenthal, H. P. \& Jusko, W. J. (1977). Breastmilk distribution of theobromine from chocolate. Journal of Pediatrics $91,477480$.

Ritchie, J. (1975). Central nervous system stimulants. 11. The xanthines. In The Pharmacological Basis of Therapeutics, 5th ed., pp. 367-378 [L. S. Goodman and A. Gilman, editors]. New York: Macmillan.

Smellie, F. W., Davis, C. W., Daly, J. W. \& Wells, J. N. (1979). Akylxanthines; inhibition of adenosine-elicited accumulation of cyclic AMP in brain slices and of brain phosphodiesterase activity. Life Sciences 24, $2475-2482$.

Technician Instruments Co. Ltd. (1971). Triglycerides. Technical Bulletin AAII-23, pp. 1-5. Tarrytown, New York: Technicon Instruments Co. Ltd.

Tyralla, E. E. \& Dodson, W. E. (1979). Caffeine secretion into breastmilk. Archives of Diseases in Childhood 54, $787-800$.

Widdowson, E. M. (1976). Changes in the body and its organs during lactation: nutritional implications. In Breast Feeding and the Mother, CIBA Foundation Symposium no. 456 (new series), pp. 102 -112. Amsterdam: Elsevier Excerpta Medica, North Holland. 
Wilde, C. J. \& Kuhn, N. J. (1979). Lactose synthesis in the rat, and the effects of litter size and malnutrition. Biochemical Journal 182, 287-294.

Williamson, D. H. (1980). Integration of metabolism in tissues of the lactating rat. FEBS Letters 117, Suppl., K93K 105.

Yurchak, A. M. \& Jusko, W. J. (1978). Theophylline secretion into breast milk, Pediatrics 57, 518-525.

Zoumas, B. L. \& Tarka, S. M. (1976). The effect of dietary theobromine on food intake and growth of rats. Federation Proceedings 35, 341 Abstr. 